\title{
PEMEROLEHAN KALIMAT TANYA BAHASA INDONESIA ANAK PRASEKOLAH USIA 5-6 TAHUN
}

\author{
Ziyadatur Rohmah, Bambang Yulianto, Maria Mintowati \\ Universitas Negeri Surabaya \\ ziyadaturrohmah@mhs.unesa.ac.id
}

DOI: http://dx.doi.org/10.32528/bb.v4i2.2122

Diterima: 11 Juni 2019

Diterbitkan: 30 Oktober 2019

\begin{abstract}
ABSTRAK
Perkembangan bahasa anak merupakan proses yang unik. Perkembangan tersebut berkaitan dengan perkembangan fisik dan otak anak. Masa perkembangan bahasa yang mendekati sempurna adalah prasekolah (5-6 tahun) karena anak telah memahami gramatikal dan memproduksi bahasa pertamanya. Pada masa ini, anak telah menyampaikan berbagai kalimat, misalnya kalimat tanya. Oleh sebab itu, tujuan penelitian ini adalah untuk mendeskripsikan pemerolehan kalimat tanya pada anak prasekolah 5-6 tahun. Jenis penelitian yang digunakan yaitudeskriptif kualitatif. Data yang diharapkan adalah kalimat tanya yang disampaikan anak. Data dikumpulkan dengan teknik simak dan dianalisis dengan teknik padan. Hasil penelitian menunjukkan bahwa: Anak prasekolah berusia lima dan enam tahun telah memperoleh kalimat tanya bahasa Indonesia. Anak prasekolah yang berusia 5 tahun telah mampu menyusun kalimat tanya biasa dengan struktur penggantian unsur kalimat berita dengan kata tanya apa, mana, dan kok serta kalimat tanya konfirmatif dengan kata iya kan yang disampaikan dengan intonasi tanya. Namun jumlahnya tidak banyak. Pemerolehan kalimat tanya pada anak usia enam tahun lebih bervariatif dibanding anak usia limat tahun. Untuk kalimat tanya biasa, anak menggunakan kata tanya apa, siapa, kenapa, dan kok serta kalimat tanya konfirmasi dengan struktur kalimat berita berintonasi tanya. Selain itu, anak juga menggunakan kata ganti apa (kah) untuk kalimat konfirmasi tersebut.
\end{abstract}

Kata kunci: pemerolehan, kalimat tanya, anak prasekolah

\section{ABSTRACT}

A Child language development is a unique process. This developments is related to the child's physical growth and brain. The child's language development has merely perfect in the period of preschool ages (5-6 years old). In this period, a child has grammatical understanding as well as ability to produce his first language. A child has also been able to state a sentence, for example interrogative one. In regard to the phenomena, the purpose of this study is to describe the child' acquisition in forming interrogative sentences in the preschool year. This study employed descriptive qualitative method. The data expected in this study are interrogative sentences performed by the child. Data was collected by teknik simak and then analyzed by teknik padan. The results of the study showed that at Preschool age, a child has acquired ability to create simple interrogative sentences in bahasa Indonesia. Preschoolers of 5 years old have been able to construct grammatically appropriate interrogative sentences by replacing declarative sentence's elements with the question word "apa", "mana", and "kok", as well as the confirming sentence with the word "iya kan" with questioning intonation. However, the amount is not much. Furthermore, the acquisition of interrogative sentences in six-year-olds is more varied. To express the common interrogative sentence, the child uses the question word "apa", "siapa", "kenapa", and "kok", and the confirming sentence with the declarative sentence 
structure of questioning. In addition, the child also uses pronoun apa(-kah) for the confirming sentence.

Keywords: acquisition, interrogative sentence, preschooler

\section{PENDAHULUAN}

Pemerolehan bahasa pada anak merupakan sebuah proses yang sangat mengesankan. Dikatakan seperti itu karena anak dilahirkan tanpa bisa berbahasa namun pada tahap tertentu anak bisa lancar berbahasa. Hal tersebut dikarenakan seorang anak dapat mengingat serta memahami suatu kata/kalimat hanya dengan sekali mendengar. Bahkan ketika sampai pada fase tertentu anak mampu menggunakan kata tersebut dengan benar sesuai dengan kegunaannya.

Chomsky dalam Subyakto dan Nababan (1993:76) menyampaikan bahwa setiap manusia memiliki kapling-kapling intelektual dalam otaknya. Salah satu kapling tersebut diisi untuk pemakaian serta pemerolehan bahasa. Kapling bahasa tersebut disebut Chomsky sebagai perangkat pemerolehan bahasa atau yang biasa disebut Language Acquisition Device (LAD).

Orang normal biasanya memperoleh bahasa pertamanya dalam waktu singkat. Hal tersebut tidak hanya dipengaruhi oleh Language Acquisition Device (LAD) itu sendiri. Menurut Chomsky lingkungan menjadi stimulus pemerolehan bahasanya. LAD dalam diri seseorang berfungsi sebagai pengolah masukan serta menentukan komponen yang harus dikuasai terlebih dahulu; mulai dari tahap penguasaan bunyi, kata, lalu frasa, kalimat, dan seterusnya. Secara tidak langsung, kemampuan berbahasa seseorang telah terprogram dan sejalan dengan perkembangan biologisnya.

Pada dasarnya, tahap pemerolehan kemampuan berbahasa meliputi proses menangkap, memahami, dan menggunakan bahasa. Proses pemerolehan bahasa berlangsung secara alami dan secara tidak sadar. Pemerolehan bahasa biasanya dihasilkan dari interaksi langsung dengan native speaker (penutur asli suatu bahasa). Selaras dengan pernyataan tersebut, Simanjuntak (1987:157) memaparkan bahwa pemerolehan bahasa adalah proses-proses yang berada di dalam otakbayi/anak-anak ketika memperoleh bahasa ibunya dan proses tersebut berlangsung tanpa disadari.

Anak mulai belajar berbicara pada usia kurang lebih 14 bulan hingga usia prasekolah dan anak dikatakan sudah menguasai "gramatikal" bahasa ibunya. Anak pada masa prasekolah atau Taman Kanak-Kanak biasanya berusia sekitar 5-6 tahun. Pada masa prasekolah, kosakata anak berkembang dengan cepat. Hal yang sama disampaikan Owens (dalam Papalia dkk, 2008:340), bahasa anak prasekolah mengalami perkembangan yang sangat pesat khususnya dalam pemerolehan kosakata dan ketatabahasaan. Selain itu, menurut Santrock (2007:362), anak pada usia prasekolah sudah mulai mampu memahami perkataan orang lain. Anak pada usia ini mulai bisa memproduksi kalimat yang terdiri dari empat sampai lima kata dan bisa berupa kalimat pernyataan, penolakan, atau bahkan pertanyaan.

Kalimat-kalimat yang disampaik anak memang tergolong sempurna. Tidak jarang anak juga menyampaikan kalimat kompleks dan rumit, serta kalimat yang ditujukan untukber bagai tujuan tertentu. Namun dalam penelitian ini hanya dibahas kalimat berdasarkan tujuannya, lebih khusus kalimat tanya. Kalimat tanya adalah kalimat yang ditujukan untuk mendapatkan jawaban. Menurut Alwi, dkk. (2010:357) kalimat tanya ditandai kata tanya seperti apa, siapa, berapa, kapan, dan bagaimana dengan atau tanpa partikel -kah sebagai penegas, diakhiri dengan tanda tanya (?) pada bahasa tulis atau intonasi yang naik pada bahasa lisan. Dan anak prasekolah telah menyampaikan kalimat Tanya tersebut. Dalam menyampaikan kalimat tanya, anak prasekolah memiliki pola keragaman. Hal tersebut ditemukan dari beberapa ucapan-ucapan anak prasekolah. Anak mulai membangun kalimat tanya dengan kata-kata ganti tanya yang bervariasi. Kalimat tanya tersebut digunakan untuk menanyakan alasan/penjelasan serta mengonfirmasi suatu hal.

Berdasarkan pernyataan-pernyataan tersebut, maka dapat dirumuskan sebuah tujuan penelitian. Tujuan penelitian ini yaitu untuk menganalisis pemerolehan kalimat Tanya bahasa Indonesia pada anak usia prasekolah usia 5-6 tahun.

Setelah didapatkan hasilnya, simpulan dari penelitian ini diharapkan dapat memberikan manfaat baik secara teoretis dan praktis. Secara teoretis, hasil dari penelitian ini diharapkan dapat menambah pemahaman terkait pemerolehan kalimat, khususnya kalimat tanya pada anak. Secara praktis ditujukan kepada orang tua dan guru agar lebih memperhatikan serta mendukung perkembangan bahasa pada anak dengan stimulusstimulus yang baik. 


\section{METODE PENELITIAN}

Dalam penelitian ini digunakan pendekatan kualitatif dengan jenis deskriptif. Penelitian dilakukan untuk mendapatkan gambaran pemerolehan kalimat tanya pada anak prasekolah. Oleh sebab itu, maka sumber data yang digunakan adalah anak-anak TK Arsyada Mulia Surabaya yang berusia 5-6 tahun. Setiap kelompok usia diambil lima anak sebagai subjek penelitian sehingga didapatkan 10 anak. Sampel tersebut telah sesuai dengan kriteria subjek yang dibutuhkan yaitu memiliki bahasa pertama yaitu bahasa Indonesia dan 5.3 bulan-5.8 bulan atau 6.3 bulan-6.8 bulan.

Dalam pengumpulan data penelitian, digunakan teknik simak dengan teknik lanjutan yaitu teknik simak bebas cakap. Sedangkan data yang digunakan adalah kalimat tanya yang digunakan anak. Data yang telah didapat selanjutnya dianalisis dengan teknik padan yang terdiri atas teknik hubung banding menyamakan serta memperbedakan. Selanjutnya, tahap penganalisisan diakhiri dengan pengabsahan data.

\section{PEMBAHASAN}

\section{A. Kalimat Tanya Bahasa Indonesia Anak Prasekolah Usia 5 tahun}

Kalimat tanya yang disampaikan anak prasekolah yang berusia lima tahun secara umum masih tergolong sederhana. Namun, telah ditemukan beberapa variasi baik dalam hal kosa kata maupun susunan kalimatnya. Berikut pemaparannya.

\section{1)Meminta Jawaban yang Berisi Penjelasan}

Kalimat pertanyaan yang bertujuan untuk meminta jawaban atas kata ganti tanya (apa, siapa, mana, berapa, kapan) telah disampaikan dengan baik oleh anak. Kalimat dengan tujuan tersebut dinyatakan anak dengan struktur penggantian unsur kalimat berita dengan kata ganti tanya tertentu. Berikut kalimat-kalimat yang ditemukan.

Konteks: Setelah guru menanyakan permainan yang disukai, anak menjawab dan menanyakan kembali pertanyaan tersebut kepada guru dengan kalimatnya sendiri.

\section{(1)“Ustazah sukanya main apa?”}

Kalimat (1) yang diproduksi anak tergolong sudah baik. Dalam kalimat tanya pada kalimat (1) tersebut memiliki struktur seperti kalimat berita namun terdapat pengisi fungsi sintaksis yang diganti dengan kata Tanya apa. Fungsi yang digantikan dalam kalimat tersebut adalah objek. Objek selalu diisi kata benda dan anak telah menggunakan kata ganti Tanya apa digunakan untuk menanyakan benda. Secara tidak langsung anak telah mengaplikasikan kata ganti apa dengan baik. Selain itu, anak usia limat tahun juga mengujarkan kata ganti tanya apa pada awal kalimat.

Konteks:Guru menanyakan boneka yang dimiliki anak tetapi anak lupa nama/sebutan boneka yang dimiliki.

\section{(2)“Apa namanya itu, Ust?”}

Berdasarkan data (2) diketahui bahwa anak usia 5 tahun telah mampu menggunakan kalimat Tanya dengan baik. Kalimat Tanya tersebut berstruktur kalimat berita dengan penggantian unsur kata ganti tanya. Yang ditanyakan dalam kalimat tersebut adalah subjek kalimat dalam kalimat berita sehingga kata ganti yang digunakan yaitu apa. Kata ganti apa biasa digunakan untuk menanyakan nama benda. Dalam hal ini anak juga telah mampu mengaplikasikan fungsi kata ganti Tanya apa di awal kalimat.

Konteks: Guru menunjukkan sebuah gambar. AFT mengatakan bahwa gambar yang ditunjuk kanmirip dengannya. KA menanyakan kemiripan wajah AFT dengan anak di dalam gambar.

\section{(3) "Mana miripnya?"}

Kalimat (3) tersebut merupakan sebuah kalimat tanya yang digunakan anak prasekolah usia 5 tahun. Dalam penyampaian kalimat tanya, anak mengutarakan dengan penggunaan kata mana. Kata ganti tanya mana biasanya digunakan untuk menanyakan letak sesuatu benda. Anak menggunakan kata ganti mana untuk menanyakan letak kemiripan teman dengan anak dalam gambar. Oleh sebab itu, kata ganti mana dalam hal ini menggantikan fungsi keterangan.

Konteks:Setelah memberikan pertanyaan kepada siswa, guru akan menjelaskan materi baru. Namun guru lupa tidak menanyakan pertanyaan yang sama kepada teman DKS. DKS menanyakan alasan guru tidak melakukan itu.

\section{(4) “Kok Lidia belum ditanyai, Ust?"}

Kalimat (4) tergolong kalimat tanya yang ditujukan untuk menanyakan alasan kepada orang lain. Dalam penyampaiannya, digunakan kata ganti kok pada awal kalimat. Kata ganti tersebut biasa disamakan dengan kata ganti tanya mengapa. Kata ganti tanya kok atau mengapa digunakan untuk menanyakan sebuah alasan. Pemilihan kata ganti tersebut cukup baik karena anak telah mampu memahami fungsi kata ganti tanya yang digunakan. Selain itu, untuk menunjukkan 
penghormatan/penegasan, kalimat tersebut diakhiri dengan sapaan kepada orang kedua yaitu Ust.

Selain itu, ditemukan pula kalimat lain yang menanyakan alasan seperti dalam kalimat (5) berikut.

Konteks: Anak menanyakan alasan teman yang bercita-cita ingin menjadi polisi. Padahal teman tersebut perempuan sedangkan polisi mayoritas laki-laki.

\section{(5) "Kok Polisi?"}

Kalimat (5) yang digunakan MBW tergolong kalimat interogatif/tanya. Kalimat tersebut memiliki struktur penggantian unsure kalimat berita namun tidak lengkap. Unsur yang digantikan tersebut yaitu keterangan sedangkan kata ganti yang digunakan anak adalah kok yang biasa disamakan dengan mengapa. Kata ganti kok/mengapa tersebut digunakan untuk menanyakan alasan suatu hal. Sehingga tepat digunakan pada kalimat (5).

Berdasarkan pemaparan yang telah dibahas, anak berusia lima tahun telah mampu menyampaikan kalimat tanya dengan struktur penggantian unsur kalimat berita dengan kata ganti tanya. Kalimat tanya dengan unsur tersebut disampaikan dengan tujuan untuk mendapatkan jawaban yang jelas. Anak menyampaikan kalimat tanya dengan kata ganti tanya apa dan mana untuk penjelasan singkat sedangkan kata ganti kok digunakan anak untuk menjapatkan jawaban berupa alasan. Oleh sebab itu, dapat disimpulkan bahwa dalam menyampaikan kalimat tanya biasa anak prasekolah berusia 5 tahun menggunakan kalimat dengan struktur kalimat berita dengan penggantian unsur tanya.

\section{2) Mengonfirmasi Suatu Keadaan}

Selain kalimat Tanya biasa, anak prasekolah juga mampu menerapkan kalimat Tanya konfirmatif. Berikut kalimat Tanya konfirmatif yang telah ditemukan.

Konteks: Guru meminta agar ASS berpindah ke tempat para siswa perempuan berkumpul. Namun, ASS menolak dan membuktikan dengan menanyakan tempat duduk aslinya kepada teman.

$$
\text { "Iyakan, Cha?" }
$$

Jika dilihat berdasarkan tujuan penyampaiannya, kalimat (6) tergolong kalimat tanya/interogatif. Kalimat tersebut memiliki pola iya $\rightarrow+$-kan, diikuti kata sapaan (nama). Kalimat tersebut disampaikan dengan intonasi akhir menaik seperti pada kalimat Tanya pada umumnya.
Kalimat Tanya dengan pola itu biasanya digunakan untuk menyampaikan kalimat Tanya konfirmatif (hanya membutuhkan jawaban iya atau tidak). Berdasar pada penjelasan-penjelasan yang telah dipaparkan, dapat disimpulkan secara keseluruhan bahwa anak prasekolah berusia 5 tahun telah memproduksi kalimat tanya. Kalimatkalimat tersebut disampaikan untuk tujuan yang variatif yaitu meminta jawaban yang sesungguhnya, meminta penjelasan atas suatu alasan, dan mengonfirmasi suatu keadaan. Kalimat yang digunakan untuk meminta jawaban dan alasan disampaikan dengan struktur penggantian suatu unsur kalimat berita dengan kata ganti tanya tertentu. Anak telah mampu memahami penggunaan kata ganti tanya misal apa, mana,dan kok (mengapa). Untuk menyampaikan pertanyaan konfirmasi, anak menyampaikan dengan kalimat tanya sederhana yaitu hanya dengan kata iyakan dan diakhiri intonasi akhir menaik.

\section{B. Kalimat Tanya Bahasa Indonesia Anak Prasekolah Usia 6 tahun}

Anak yang berusia 6 tahun secara usia serta perkembangannya lebih mendahului anak usia lima tahun. Oleh sebab itu, kalimat tanya yang digunakan juga lebih bervariasi. Berikut kalimatkalima tanya yang disamaikan anak prasekolah yang berumur enam tahun.

\section{1) Meminta Jawaban yang Berisi Penjelasan}

Kalimat yang digunakan untuk meminta jawaban yang berisi penjelasan biasa disebut kalimat tanya biasa. Kalimat tersebut telah mampu dengan baik diperformansikan oleh anak prasekolah yang berusia enam tahun. Bahkan, anak telah menggunakannya dengan beragam variasi. Berikut variasi-variasi kalimat tanya yang digunakan anak usia 6 tahun.

Konteks: Ketika pembelajaran berlangsung, guru tiba-tiba memotret kegiatan anak-anak. Karena sadar,VEP menanyakan alasan guru memotret kegiatan kelas yang berfokus pada VEP.

\section{(7) “Kenapa aku difoto?”}

Kalimat (7) merupakan kalimat tanya jika dilihat berdasarkan tujuan penyampaiannya. Kalimat tersebut disusun atas struktur kalimat berita dengan penggantian unsur kata ganti tanya tertentu. Kalimat tersebut disampaikan untuk mendapatkan jawaban yang berupa alasan. Dalam kalimat tersebut digunakan kata ganti tanya kenapa (bentuk tidak baku mengapa). Kata kenapa yang biasa digunakan untuk menanyakan suatu alasan. Dan anak prasekolah yang berusia enam tahun telah menggunakannya dengan tepat. 
Selain kata kenapa, untuk menanyakan suatu alasan anak juga menggunakan kata ganti tanya kok. Hal tersebut tampak pada data berikut.

Konteks: Anak terkejut karena secara tidak sengaja ditunjuk lagi untuk memperkenalkan diri. Itu sebabnya, BRM meminta alasan dirinya kembali diberi perintah.

\section{(8) “Kokakulagi?"}

Kalimat (8) yang diperformansikan anak usia 6 tahun tersebut tergolong kalimat tanya biasa karena benar-benar ditujukan untuk mencari jawaban berupa penjelasan (alasan). Dalam kalimat (8) anak menggunakan kata ganti tanya kok yang biasa disejajarkan dengan kata tanya mengapa. Kata ganti tersebut diletakkan anak pada awal kalimat. Kata ganti tanya mengapa seperti yang telah disampaikan pada anaisis sebelumnya digunakan untuk menanyakan suatu jawaban berupa alasan. Dalam kalimat, alasan biasanya menjadi pengisi fungsi keterangan sebab.

Selain yang telah disebutkan, anak menyampaikan kalimat tanya lain. Berikut kalimat yang ditemukan.

Konteks: Guru memberikan sebuah pertanyaan. Anak mengatakan kalimat tanya juga sambil memikirkan jawabannya.

\section{(9) “Apa ya?”}

Kalimat (9) yang digunakan NZP tergolong kalimat tanya (interogatif). Kalimat yang digunakanan anak tersebut hanya terdiri atas kata ganti tanya yaitu apa. Meskipun tergolong sangat sederhana, kalimat (9) tetap dapat dipahami oleh orang lain karena merujuk pada dialog sebelumnya. Kata apa tersebut digunakanuntuk menanyakan sesuatu. Kata ganti tanya apa biasa digunakan dalam kalimat tanya yang jawabannya merujuk pada sua benda/konsep/pemikiran. Sehingga tepat digunakan anak.

Pada kalimat-kalimat sebelumnya, kata ganti tanya digunakan pada awal kalimat. Namun pada data berikut kata ganti tanya diterapkan pada akhir kalimat.

Konteks: Seorang teman bercita-cita untuk menjadi polisi. Lalu, KRR menanyakan orang yang akan ditembak setelah menjadi polisi.

\section{(10) “Nembak siapa?"}

Kalimat (10) merupakan contoh kalimat tanya yang disampaikan oleh anak prasekolah usia lima tahun. Kalimat tersebut disampaikan anak untuk mendapatkan jawaban yang diinginkan. Yang ditanyakan dalam kalimat tersebut adalah objek atau sasaran tindakan. Dalam penyampaiannya, digunakan kata ganti tanya siapa. Kata ganti tanya siapa merupakan kata ganti yang dikhususnkan untuk menanyakan orang. Struktur yang digunakan anak tersebut sebenarnya sama dengan kalimat berita tidak lengkap. namun terdapat penggantuan unsur yaitu objek yang digantikan dengan kata ganti tanya.

Selain dengan menggunakan kata ganti tanya untuk meminta suatu penjelasan, anak juga memperformansikan kalimat tanya tanpa penggunan kata ganti tanya.

Konteks:Guru memberikan bintang pada tiap-tiap anak yang berhasil menyelesaikan tugas dengan baik. Anak telah menyelesaikan tugas namun belum mendapatkan bintang dari guru.

(11) “Ust, bintangnya?"

Kalimat (11) tersebut merupakan kalimat tanya yang digunakan anak prasekolah. Dalam menyampaikan kalimat tersebut, anak tidak menggunakan satu pun kata tanya. Anak hanya menyampaikan kalimat tersebut dengan intonasi akhir menaik seperti pada pengujaran kalimat tanya secara umum. Meski kurang jelas dan sempurna, kalimat tersebut masih bisa dipahami oleh guru karena selain menyatakan kalimat anak juga menyodorkan tangannya untuk mendapatkan bintang yang diinginkan.

Berdasarkan data-data yang telah ditujukkan di muka dapat disimpulkan bahwa anak prasekolah dalam menyampaikan kalimat tanya yang ditujukan untuk mendapatkan jawaban berupa penjelasan anak mempergunakan struktur penggantian unsur kalimat berita (deklarasi) dengan kata ganti tanya. Untuk menyampaikan kalimat yang ditujukan untuk mendapatkan jawaban berupa alasan anak menyampaikan kalimat tanya dengan penggunaan kata ganti kenapa dan kok yang biasanya disetarakan dengan mengapa. Selain itu, kata ganti apa dan siapa juga telah mampu diproduksi. Selain dengan kata ganti tanya, anak prasekolah juga memperformansikan kalimat tanya tanpa adanya kata ganti tanya apapun tetapi digantikan dengan adanya intonasi tanya.

\section{2) Mengonfirmasikan Suatu Keadaan}

Kalimat tanya konfirmasi biasanya memiliki struktur kalimat berita yang disampaikan dengan intonasi tanya. Oleh sebab itu, intonasi yang digunakan harus tepat karena menajdi faktor penting keberterimaan kalimatnya. Kalimat-kalimat tanya konfirmatif disampaikan untuk mendapatkan jawaban singkat yaitu ya/tidak. Anak prasekolah yang berusia enam tahun telah memproduksi 
kalimat tanya biasa. Namun selain itu, anak juga telah mampu menyampaikan kalimat dengan tujuan untuk mengonfirmasi suatu hal dengan beragam variasi. Berikut data-data yang telah ditemukan beserta penganalisisannya.

Konteks:Guru mengajak anak melakukan perkenalan sekali lagi. Anak mengonfirmasi dengan mengajukan pertanyaan.

\section{(12) “Kemarin kita sudah kenalan kan, Ust?"}

Kalimat (12) yang disampaikan oleh anak berusia enam tahun tersebut digolongkan dalam kalimat interogatif (tanya). Kalimat tersebut disampaikan anak untuk memastikan/mengonfirmasi kan suatu keadaan sehingga tidak dibutuhkan jawaban panjang cukup dengan jawaban ya/tidak. Jika dilihat dari strukturnya, kalimat (12) tersebut sebenanya berstruktur seperti kalimat berita pada umunya tetapi disampaikan dengan intonasi kalimat tanya. Kalimat tersebut memiliki pola "keterangan + subjek + predikat + partikel'kan+ sapaan".

Konteks: Terdapat guru baru yang masuk ke kelas. Anak menanyakan identitas guru tersebut.

\section{(13) “Ustazah baru ya?"}

Berdasaran kalimat (13) anak telah mampu menyampaikan kalimat Tanya dengan tujuan mengonfirmasi. Susunan kalimat tersebut sama dengan kalimat berita yang diujarkan dengan intonasi akhir menaik seperti pada kalimat interogatif pada umumnya. Kalimat tersebut berpola SP (subjek + predikat) dan terdapat penambaha nya. Karena bentuknya seperti kalimat pernyataan maka intonasi yang digunakan ditata dengan tepat. Dan anak prasekolah yang berusia 6 tahun telah mampu memahami itu.

Selain data yang telah dipaparkan sebelumnya, terdapat kalimat yang juga merupakan kalimat tanyak konfirmatif.

Konteks:Kalimat tersebut digunakan untuk menanyakan kebenaran terkait kebiasaan MAR (Koko) yang tidak pernahm akan nasi.

\section{(14) “Jadi, Koko gak pernah makan nasi?"}

Seperti pada data sebelumnya, kalimat (14) merupakan contoh kalimat tanya yang diperformansikan dengan tujuan untuk mengonfirmasi suatu pernyataan. Kalimat tersebut memiliki struktur seperti kalimat berita yaitu konjungsi jadi + SPO?. Dalam kalimat tersebut fungsi subjek diisi kata Koko, sedangkan pengisi predikatnya yaitu frasa nggak pernah makan, dan kata nasi merupakan pengisi fungsi objek. Jika dikaitkan dengan kelengkapan unsur, kalimat tersebut tergolong lengkap. Namun karena diucapkan dengan intonasi tanya maka kalimat tersebut bukan tergolong kalimat berita.

Dalam menyampaikan kalimat tanya konfirmasi, anak prasekolah yang berusia 6 tahun menggunakan kata ganti tanya untuk meminta jawaban ya/tidak seperti pada kalimat (15).

Konteks:Terdapat teman yang tidak mau melakukan perintah guru. MAR memberikan kemungkinan alasan teman tidak menuruti perintah guru.

\section{(15) "Apa dia mau sama Andin?"}

Data (15) yang digunakan anak merupakan kalimat tanya yang ditujukan untuk mengonfirmasi suatu keadaan. Kalimat kofirmasi yang digunakan anak tersebut berstruktur kalimat berita dengan penggunaan kata ganti tanya apa pada awal kalimat. Kata tanya apa yang dimaksud anak yaitu apakah. Apabila dipolakan maka tersusun kata tanya (apa) dan pengisi fungsi sintaksis subjek, predikat, dan keterangan. Meskipun berpola kalimat berita namun kalimat tersebut disampaikan dengan intonasi kalimat tanya sehingga dibutuhkan jawaban dingkat yaitu ya/tidak.

Berdasarkan data yang telah di bahas, disimpulkan bahwa anak prasekolah yang berusia enam tahun telah mampu menyampaikan kalimat Tanya konfirmasi yang lebih variatif. Dalam menyampaikan kalimat Tanya konfirmasi anak menggunakan pola kalimat berita dengan struktur utama. Meski dengan struktur kalimat berita, anak menyampaikannnya dengan intonasi tanya dan bermaksud meminta jawaban berupa ya/tidak. Selain itu, ditemukan pula kalimat Tanya konfirmasi dengan penggunaan kata ganti Tanya apa seperti pada kalimat Tanya biasa (yang membutuhkan penjelasan). Namun bedanya kalimat tersebut ditujukan hanya untuk mengonfirmasi suatu hal.

Berdasarkan simpulan dari kedua subjudul di muka, maka dapat ditarik simpulan secara umum bahwa anak prasekolah yang berusia enam tahun telah menyampaikan dua macam jenis kalimat tanya dengan berbagai macam variasi. Dalam menyampaikan kalimat tanya biasa yang ditujukan agar mendapat penjelasan, anak mempergunakan kalimat tanya dengan struktur penggantian unsur kalimat deklarasi (berita) dengan kata ganti tanya. Untuk mendapatkan jawaban berupa alasan, anak prasekolah usia enam tahun menyampaikan kalimat tanya dengan menggunakan kata ganti tanya kenapa dan kok. Untuk mendapatkan jawaban berupa barang/benda/konsep anak menggunakan kalimat tanya dengan kata ganti apa dan siapa. Selain dengan penggunaan kata tanya, anak juga 
menyampaikan kalimat tanya untuk mendapatkan jawaban penjelasan atau tindakan hanya dengan intonasi tanya tanpa kata tanya. Selanjutnya, dalam menyampaikan kalimat tanya dengan tujuan untuk mengonfirmasi (konfirmatif) rerata anak mengujarkan kalimat tanya dengan struktur kalimat berita yang diintonasikan seperti kalimat tanya umumnya yaitu nada akhir menaik. Selain itu, anak juga menyampaikan kalimat tanya konfirmasi dengan penggunaan kata ganti tanya apa.

\section{SIMPULAN}

Berdasarkan analisis yang telah dilakukan, dapat disimpulkan bahwa anak prasekolah yang berusia lima dan enam tahun telah memperoleh kalimat tanya dalam bahasa Indonesia. Anak prasekolah yang berusia 5 tahun telah mampu menyusun kalimat tanya biasa dengan struktur penggantian unsur kalimat berita dengan kata tanya. Kata tanya yang digunakan antara lain: apa, mana, dan kok. Kata ganti kok digunakan anak untuk menanyakan sebuah alasan. Selain itu, anak lima tahun juga menyampaikan kalimat tanya konfirmatif hanya dengan kata iyakan yang diucapkan dengan intonasi tanya. Namun jumlahnya tidak banyak. Selanjutnya, pemerolehan kalimat tanya pada anak prasekolah usia enam tahun lebih bervariatif dibanding anak usia limat tahun. untuk menyatakan kalimat tanya biasa (mendapatkan penjelasan), anak menggunakan kata tanya apa, siapa, kenapa, dan kok. Kata ganti tanya kenapa dan kok digunakan anak untuk menanyakan alasan. Selain itu, anak prasekolah usia enam tahun juga telah menyampaikan beberapa kalimat tanya dengan tujuan mengonfirmasi. Struktur kalimat yang digunakan untuk kalimat tanya konfirmasi yaitu struktur kalimat berita dengan intonasi tanya. Selain itu, anak juga menggunakan kata ganti apa (-kah) untuk kalimat konfirmasi tersebut.

\section{DAFTAR RUJUKAN}

Alwi, Hasan dkk. 2010. Tata Bahasa Baku Bahasa Indonesia. Jakarta: Balai Pustaka.

Nababan, Subyakto.1993. MetodologiPengajaran Bahasa. Jakarta: GramediaPustaka Utama.

Papalia, Diane E. 2008. Human Development (Psikologi Perkembangan). Jakarta: Prenada Media Group.

Santrock, Jhon W. 2007. Perkembangan Anak. Jakarta: Penerbit Erlangga.
Simanjuntak, Mangantar. 1987. Pengantar Psikolinguistik Modern. Kuala Lumpur: Dewan Bahasa dan Pustaka. 
Rohmah, Yulianto, Mintowati. PEMEROLEHAN KALIMAT TANYA BAHASA INDONESIA ANAK... 